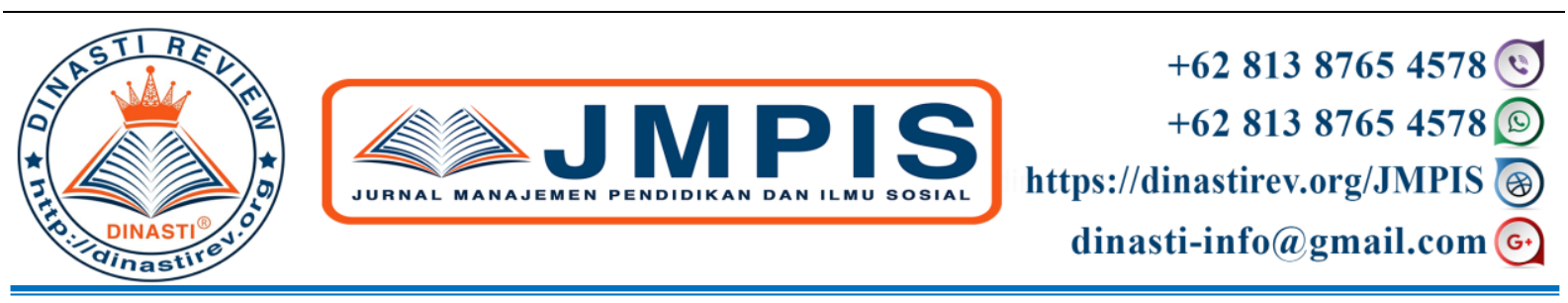

\title{
PENGEMBANGAN BUKU DONGENG BERBASIS KEARIFAN LOKAL JAMBI UNTUK SISWA KELAS II SD/MI
}

\section{Susmawati}

1) Magister Pendidikan Dasar, Pascasarjana Universitas Jambi, Indonesia

ARTICLE INFORMATION

Received: 25 Juni 2020

Revised: 3 Juli 2020

Issued: 10 Juli 2020

Corresponding author: first author E-mail:

susmawati53@gmail.com

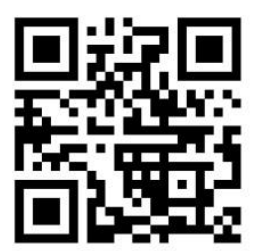

DOI:10.38035/JMPIS
Abstrak: Penelitian ini dilatarbelakangi oleh rendahnya minat baca dan belum adanya ketersediaan media untuk mengenal budaya Jambi. Tujuan penelitian ini; 1) Mengembangkan produk berupa buku dongeng berbasis kearifan lokal Jambi. 2) Mengetahui kevalidan dan kemenarikan buku dongeng berbasis kearifan lokal Jambi. Penelitian ini merupakan penelitian pengembangan, menggunakan model 4-D modifikasi Trianto (Define, Design, Development, and Dessiminate). Validasi dilakukan kepada Ahli Media, Ahli Bahasa dan materi untuk mengetahui kevalidan produk. Skor rata-rata yang diperoleh dari Ahli media 4.48 dengan kategori sangat baik, validasi bahasa dan materi memperoleh skor $>85 \%$ dengan kategori sangat baik, dan respon guru $98 \%$ dengan kategori sangat praktis. Hasil tersebut menunjukkan bahwa produk valid dan menarik untuk di uji cobakan pada kelas II. Berdasarkan hasil wawancara, sebagian besar siswa memberikan respon positif dengan menyatakan bahwa buku dongeng berbasis kearifan lokal Jambi sangat menarik dan praktis.

Kata Kunci: Buku Dongeng, Kearifan Lokal Jambi

\section{PENDAHULUAN}

Masyarakat saat ini lebih mengenal budaya modern dibandingkan budaya dan kearifan lokal setempat. Sehingga, budaya dan kearifan lokal setempat, semakin lama semakin hilang. Banyak orang bertempat tinggal di Jambi, namun tidak mengetahui sejarah Jambi. Menurut Sugianto, (2015:72), menjelaskan bahwa secara etimologis, kearifan (wisdom) berarti kemampuan seseorang dalam menggunakan akal pikirannya untuk menyikapi suatu kejadian, objek atau situasi. Sedangkan lokal menjukkan ruang interaksi dimana peristiwa atau situasi itu terjadi. Oleh karena itu, budaya dan kearifan lokal Jambi harus diperkenalkan kepada siswa sejak dini melalui materi dongeng yang terdapat pada kurikulum 2013.

Kurikulum 2013 merupakan kurikulum pembelajaran yang sedang berlaku dan diterapkan di Indonesia. Pada kuriulum 2013, terdapat pembelajaran yang disebut dengan pembelajaran tematik. Pembelajaran tematik adalah pembelajaran yangmenyatukan beberapa subtema menjadi satu tema pembelajaran. Pembelajaran tematik terdapat beberapa materi salah satunya adalah materi dongeng. Dongeng merupakan metode 
warisan nusantara yang digunakan dalam menyampaikan pembelajaran ataupun cerita yang paling menyenangkan dan mudah dimengerti.

Dongeng, pada saat ini yang sering dikenalkan kepada masyarakat dan yang disajikan pada kurikulum 2013, kelas II SD/MI tema 7 yakni dongeng fabel (dongeng binatang). Sangat minim sekali dongeng-dongeng berbasis budaya dan kearifan lokal diwilayah setempat, khususnya wilayah Jambi. Sehingga, dongeng Jambi hanya terseimpan pada buku sastra lama saja, tidak dikembangkan atau diperkenalkan kepada masyarakat dan generasi. Sehingga perlunya pengenalan budaya dan kearifan lokal melalui dongeng. Kegiatan belajar dongeng tersebut, tentunya sangat membuatuhkan media yang dapat meningkatkan kemampuan imajinasi, kreasi, dan psikomotorik. Dan tentunya memiliki manfaat dan fungsinya untuk memudahkan guru dalam menyampaikan pembelajaran dan memudahkan peserta didik dalam menerima materiyang disampaikan oleh guru.

Pada buku tematik kelas II, materi dongeng tidak dibahas secara lengkap dan jelas. Sehingga peserta didik tidak memiliki kemampuan untuk mendongeng dan memahami definisi dongeng dengan jelas. Kegiatan belajar dongeng, tentunya membutuhkan media ataupun bahan ajar tambahan untuk menunjang pembelajaran dongeng pada buku tematik kelas II tema 7 tersebut. Baik dari penyajian materi yang lebih lengkap dan ilustrasi yang lebih menarik, sehingga dapat meningkatkan minar baca, menulis, mendengarkan dongeng, dan menceritakan kembali atau mendongeng di depan kelas.

Berdasarkan latar belakang yang telah penulis paparkan, maka penulis melakukan pengembangan media dongeng berbasis kearifan lokal Jambi sebagai media siswa kelas II sesuai dnegan kompetensi yang ingin di capai agar dapat menjadi solusi bagi guru dalam menyampaikan dan menerima materi dongeng yang disampaikan oleh fasilitator. Selain berdasarkan kompetensi, media ini juga memiliki tujuan sebagai jembatan untuk mengenalkan dongeng kearifan lokal Jambi kepada peserta didik melalui dongeng yang disampaikan pada media tersebut.

\section{KAJIAN PUSTAKA \\ Media Pembelajaran \\ Definisi Media Pembelajaran}

Media pembelajaran merupakan alat yang digunakan oleh guru untuk menyampaikan pembelajaran kepada peserta didik. Menurut Wati (2016) Media erat kaitannya dengan proses pembelajaran. Kata media berasal dari bahasa latin, yaitu medius. Arti kata medius adalah tengah, perantara atau pengantar. Menurut Bovee (1977) dalam Asyar (2010), istilah "tengah, perantara, pengantar" tersebut digunakan karena fungsinya sebagai perantara atau pengantar pesan dan informasi dari si pengirim pesan pesan kepada si penerima pesan. Dalam hal ini guru sebagai fasilitator

\section{Fungsi Media Pembelajaran}

Berdasarkan kegunaan pengembangannya, media memiliki fungsi sebagaimana yang dipaparkan oleh Menurut Wati (2016). Fungsi media yakni, fungsi atensi; menarik mengarahkan siswa konsetrasi siswa untuk belajar. Fungsi fektif, nyaman dan menggugah emosi dan sikap siswa. Fungsi kognitif, yakni tampilan dan isi media harus menggugah 
kemampuan koognitif siswa. Fungsi kompensatoris, yakni dengan menggunakan media yang dikembangkan dapat emudahkan siswa dalam mengingat kembali materi yang disampaikan.

\section{Manfaat Media Pembelajaran}

Pembelajaran merupakan proses interaksi antara guru dan peserta didik untuk mencapai suatu kompetensi dalam pembelajarann, Asyar (2010) mengemukakan beberapa manfaat media pembelajaran diantaranya yakni; dapat memperluas cakrawala sajian materi pembelajaran. Dapat meningkatkan motivasi belajar dan menambah pengetahuan serta pengalaman baru. Dapat memberikan pengalaman belajar yang konkret dan langsung kepada peserta didik. Memudahkan peserta didik untuk mencapai standar kompetensi. Penggunaan media dapat memecahkan masalah yang dihadapi guru dan peserta didik.

\section{Dongeng Berbasis Kearifan Lokal Jambi}

\section{Definisi Dongeng}

Menurut Amirudin dan Bakar (2002:47), “dongeng adalah cerita khayal semata, tidak pernah terjadi. Salah satu cerita binatang yang menjadi suri tauladan bagi manusia. Pelaku utama dalam cerita tersebut bisa bicara seperti manusia. Contohnya, dongeng Si Kancil”. Menurut Sarumpaet (2009:2), menyatakan bahwa dongeng juga merupakan bagian sastra anak. Dimana cerita-cerita yang berkenaan dengan budaya atau kearifan lokal setempat bisa di sastrakan dalam bentuk dongeng sesuai dengan kebutuhan dan psikologi peserta didik.

\section{Definisi Kearifan Lokal}

Dalam pengertian Kamus Besar Bahasa Indonesia (KBBI), kearifan lokal (local wisdom) terdiri dari dua kata: kearifan (wisdom) dan lokal (local). Dalam Kamus Inggris Indonesia Echols dan Syadily, local berarti setempat, sedangkan wisdom (kearifan) sama dengan kebijaksanaan. Secara umum maka local wisdom (kearifan setempat) dapat dipahami sebagai gagasan-gagasan setempat (local) yang bersifat bijaksana, penuh kearifan, bernilai baik, yang tertanam dan diikuti oleh anggota masyarakatnya. Menurut Ida Sugianto, (2015:72), menjelaskan bahwa secara etimologis, kearifan (wisdom) berarti kemampuan seseorang dalam menggunakan akal pikirannya untuk menyikapi suatu kejadian, objek atau situasi. Sedangkan lokal menjukkan ruang interaksi dimana peristiwa atau situasi itu terjadi.

\section{Buku Dongeng Berbasis Kearifan Lokal Jambi}

Buku dongeng berbasis kearifan lokal Jambi dikembangkan sebagai solusi untuk mengatasi problem dan sebagai suplementari buku tematik kelas II tema 7. Buku dongeng tersebut dikembangkan dengan 3 dongeng kearifan lokal Jambi, bertujuan untuk menyampaikan local wisdom Jambi kepada peserta didik melalui dongeng yang disampaikan.

\section{METODE PENELITIAN}

Penelitian ini menggunakan metode Research \& Development (R\&D). Penelitian ini menghasilkan produk berupa buku dongeng berbasis kearifan lokal Jambi sebagai media untuk siswa kelas II SD/MI. Produk tersebut dikembangkan dengan menggunakan model pengembangan 4-D (Define, Design, Development, Disseminate) yang dimodifikasi dari model pengembangan Thiagarajan (Trianto, 2014). 


\section{Jenis Penelitian}

Penelitian ini merupakan penelitian pengembangan. Menurut Sugiyono (2014:407) "Penelitian pengembangan adalah metode penelitian yang digunakan untuk menghasilkan produk tertentu dan menguji keefektifan produk tersebut". Penelitian pengembangan pendidikan merupakan upaya menciptakan atau mengembangkan produk yang telah ada menjadi produk pembelajaran berupa media dan lainnya yang lebih menarik lagi.

\section{Waktu dan tempat Penelitian}

Penelitian ini dilaksanakan di MI Al-Munawwarah Kota Jambi. Waktu penelitian yang direnanakan dimulai pada 13 Desember 2019 hingga Februari 2020.

\section{Sumber Data}

Sumber data dalam penelitian pengembangan ini meliputi validator ahli media dan desain, ahli materi dan bahasa. Kepala sekolah(Sebagai informan), guru (sebagai informan dan responden) dan peserta didik kelas II mi Al-Munawwarah Kota Jambi sebagai subyek uji coba.

\section{Teknik Pengumpulan Data}

Penelitian ini menggunakan teknik pengumpulan data sebagai berikut:

\section{Angket}

Menurut Sugiono (2015:119) kuesioner merupakan teknik pengumpulan data yang dilakukan dengan cara memberi seperangkat pertanyaan atau pertanyaan tertulis kepada responden untuk dijawabnya. Pada penelitian pengembangan ini, angket digunakan oleh penulis untuk validasi produk kepada ahli media dan desain, ahli bahasa dan respon guru. Angket yang digunakan menggunakan skala likert, dengan skor penilaian 1) Kurang, 2) Cukup, 3) Baik, 4) Sangat Baik.

\section{Wawancara Terstruktur}

Wawancara terstruktur terkait dengan informasi yang dibutuhkan penulis untuk memperoleh data pada pra-penelitian dan proses penelitian dengan menggunakan pedoman pertanyaan secara terstruktur. Wawancara dilakukan kepada kepala sekolah terkait pelaksanaan pembelajaran dongeng di kelas II, keadaan sekolah dan media serta bahan ajar yang digunakan. Wawancara yang dilakukan kepada guru kelas II, terkait dengan prancangan pembelajaran, pelaksanaan pembelajaran, bahan ajar serta media yang digunakan pada pembelajaran dongeng sebelumnya dan respon terhadap buku dongeng yang dikembangkan. Kepada siswa, untuk mengetahui respon kemenarikan produk yang dikembangkan.

\section{Dokumentasi (documentation)}

Data dokumentasi menghimpun dokumen-dokumen tentang berbagai kegiatan dan program-program sekolah yang berkaitan dengan fokus penelitian. Seperti foto kegiatan proses kegiatan pembelajaran, bahan ajar yang digunakan, dan lain sebagainya. Data tersebut dapat memperkuat data hasil penelitian lainnya. 


\section{Teknik Analisis Data}

Analisis data dilakukan untuk mengetahui hasil penelitian. Teknik analisis data pada penelitian ini merupakan analisis deskriptif kuantitatif dan kualitatif, digunakan untuk mengolah data dari hasil validasi ahli materi, desain, dan materi pembelajaran serta respon guru terhadap buku dongeng yang digunakan. Data yang telah dikumpulkan pada lembar validasi terlebih dahulu diubah kedalam kuantitatif sesuai dengan bobot skor. Pengubahan tersebut mengunakan rumus sebagai berikut:

$$
P=\frac{\Sigma \mathrm{x}}{\Sigma \mathrm{xi}} \times 100 \%
$$

$$
\begin{aligned}
& \text { Keterangan: } \\
& \mathrm{P} \quad=\text { Persentase } \\
& \sum x \quad=\text { Jumlah total jawaban skor validator (nilai nyata). } \\
& \sum x i \quad=\text { Jumlah total skor jawaban tertinggi (nilai harapan). } \\
& 100 \%=\text { Konstanta. }
\end{aligned}
$$

Skor produk yang telah divalidasi dapat ditentukan dengan kriteria sebagai berikut:

Tabel 1. Kriteria Kevalidan Angket Penilaian Validator. (Prasetyo, perwiningtyas, 2017: 23).

\begin{tabular}{|c|l|}
\hline Skala Nilai (\%) & \multicolumn{1}{c|}{ Tingkat Validitas } \\
\hline $85,01-100,00$ & Sangat valid, tidak perlu revisi. \\
\hline $70,01-85,00$ & Valid, dapat digunakan tetapi perlu revisi kecil \\
\hline $50,01-70,00$ & Kurang valid, dapat digunakan tetapi revisi besar \\
\hline $01,00-50,00$ & Tidak valid, tidak boleh dipergunakan \\
\hline
\end{tabular}

Tabel 1. Tersebut perupakan kriteria kevalidan produk. Apabila memenuhi syarat dengan pencapaian skor >50,01-100 dari penilaian kuesioner yang telah divalidasi oleh validator. Produk yang sudah divalidasi tetapi belum mencapai skor maksimal harus dilakukan pengulangan revisi hingga produk benar-benar dapat dikatakan valid.

\section{Analisis Kemenarikan Buku Dongeng Berbasis Kearifan Lokal Jambi}

Kemenarikan buku dongeng penulis lakukan dengan melakukan wawancara kepada peserta didik kelas II MI Al-Munawwaroh Kota Jambi untuk mengetahui respon peserta didik terhadap produk yang dikembangkan.

\section{HASIL DAN PEMBAHASAN \\ Hasil}

Penelitian ini merupakan penelitian pengembangan dengan hasil produk yang dikembangkan berupa buku dongeng berbasis kearifan lokal Jambi sebagai media dongeng bagi siswa kelas II MI AlMunawwarah Kota Jambi. Dengan hasil validasi dan uji coba sebagai berikut: 


\section{Validasi Media dan Desain}

Validasi media dan desain dilakukan kepada ahli, dengan hasil validasi sebagai berikut:

Tabel 2. Rekapitulasi Hasil Validasi Media dan Desain

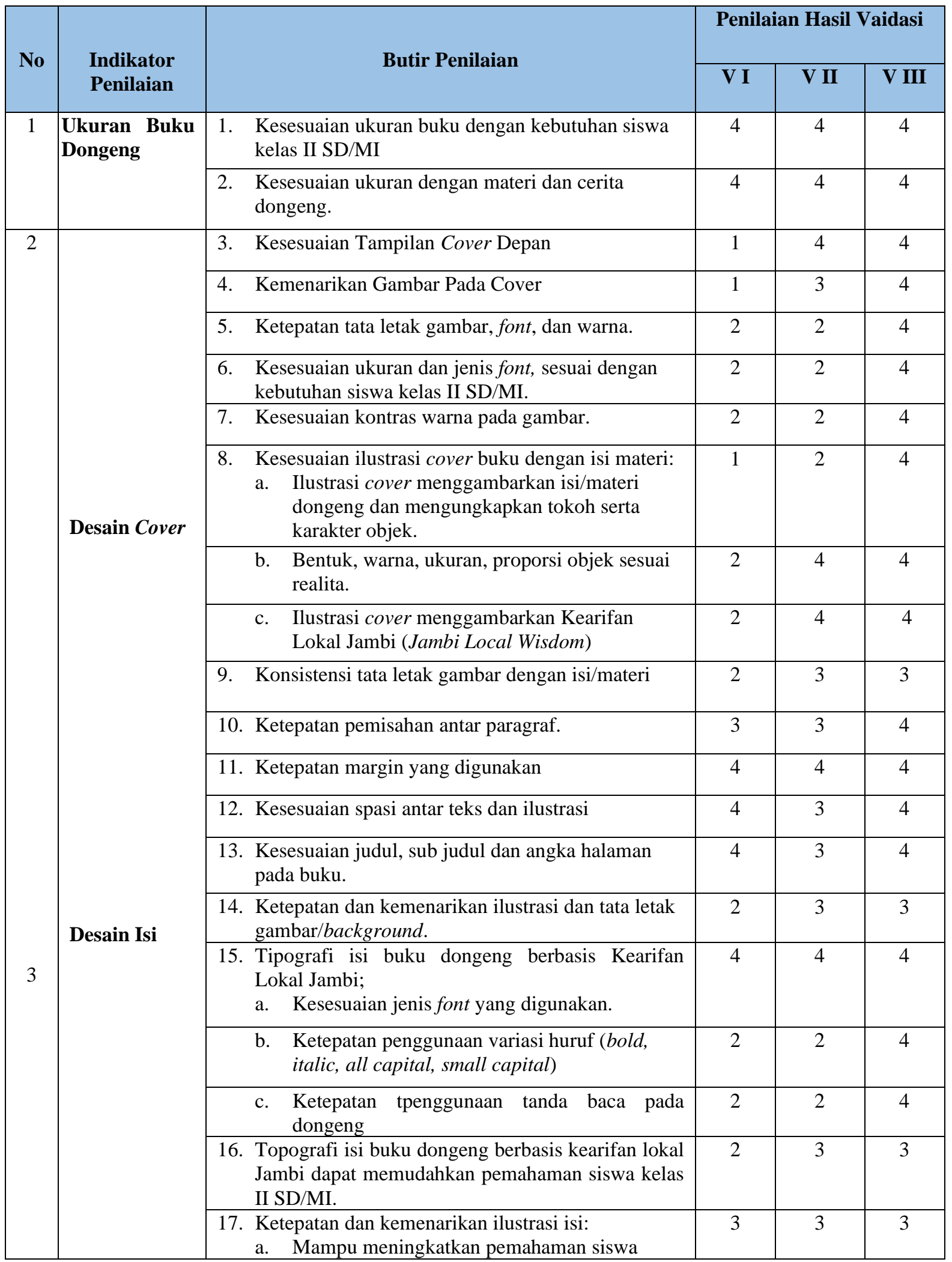




\begin{tabular}{|c|c|c|c|c|}
\hline \multirow{2}{*}{} & b. Kreatif dan dinamis & 3 & 3 & 3 \\
\cline { 2 - 5 } & c. Sesuai untuk siswa kelas II SD/MI & 2 & 4 & 4 \\
\cline { 2 - 5 } & $\begin{array}{l}\text { 18. Kemenarikan dan kesesuaian desain dan ilustrasi } \\
\text { pada evaluasi dongeng. }\end{array}$ & 3 & 4 & 4 \\
\hline \multicolumn{2}{|c|}{ Jumlah } & 61 & 69 & 91 \\
\hline \multicolumn{2}{|c|}{ Rata-rata } & 94 & 94 & 94 \\
\hline \multicolumn{2}{|c|}{ Persentase validitas } & $\mathbf{6 4 , 8 \%}$ & $\mathbf{7 3 , 4 \%}$ & $\mathbf{9 6 , 8 \%}$ \\
\hline
\end{tabular}

Tabel 2. Di atas merupakan perolehan skor dari hasil validasi media desain. Berdasarkan saran validator, skor validitas pertama dan menunjukkan angka yang masih rendah, sehingga penulis harus merevisi produk sebagaimana saran yang diberikan. Pada validasi ketiga, penulis memperoleh angka yang cukup lumayan dengan kriteria sangat valid. Sehingga produk dapat diujikan dengan sedikit perbaikan.

\section{Validasi Materi dan Bahasa}

Validasi ahli materi dan bahasa dilakukan untuk mengetahui kevalidan produk pada bagian ketepatan penulisan, dan pengunakan bahasa pada buku dongeng. Validasi materi dan bahasa dilakukan kepada ahli bahasa dengan hasil validasi sebagai berikut:

Tabel 3. Hasil Validasi Materi dan Bahasa

\begin{tabular}{|c|c|c|c|c|}
\hline \multirow[b]{2}{*}{ No } & \multirow[b]{2}{*}{ Indikator } & \multirow[b]{2}{*}{ Deskripsi } & \multicolumn{2}{|r|}{ Hasil } \\
\hline & & & Skor & Komentar \\
\hline \multirow[t]{5}{*}{1} & \multirow{5}{*}{$\begin{array}{l}\text { Penggunaan } \\
\text { bahasa }\end{array}$} & Kejelasan petunjuk dan kalimat perintah. & 4 & Sangat Baik \\
\hline & & $\begin{array}{l}\text { Kemenarikan bahasa untuk memotivasi dan meningkatkan } \\
\text { rasa ingin tahu siswa belajar dongeng. }\end{array}$ & 4 & Sangat Baik \\
\hline & & Kekomunikatifan bahasa. & 4 & Sangat Baik \\
\hline & & $\begin{array}{l}\text { Penggunaan bahasa bersifat baku dan lues serta mudah } \\
\text { dimengerti peserta didik kelas rendah. }\end{array}$ & 3 & Baik \\
\hline & & $\begin{array}{l}\text { Kesesuaian bahasa dengan kemampuan berpikir, tingkat } \\
\text { pengembangan sosial dan emosional peserta didik kelas II }\end{array}$ & 3 & Baik \\
\hline \multirow[t]{7}{*}{2} & \multirow{4}{*}{$\begin{array}{l}\text { Ketepatan } \\
\text { dialog/teks } \\
\text { dengan } \\
\text { cerita/materi }\end{array}$} & Kesesuaian tema dengan alur cerita. & 3 & Baik \\
\hline & & Kemenarikan dialog/cerita dongeng. & 4 & Sangat Baik \\
\hline & & Kesesuaian dongeng dengan kearifan lokal Jambi. & 4 & Sangat Baik \\
\hline & & $\begin{array}{l}\text { Kemenarikan dan kesesuaian cerita dongeng untuk siswa } \\
\text { kelas II. }\end{array}$ & 4 & Sangat Baik \\
\hline & & Kelengkapan materi yang disajikan. & 3 & Baik \\
\hline & & Keluasan dan kemenarikan materi. & 3 & Baik \\
\hline & & Kesesuaian petunjuk menulis dongeng untuk siswa kelas II. & 3 & Baik \\
\hline
\end{tabular}




\begin{tabular}{|c|c|c|c|c|}
\hline \multirow[t]{2}{*}{3} & \multirow{2}{*}{$\begin{array}{l}\text { Penyajian } \\
\text { materi }\end{array}$} & Kemenarikan materi dan dongeng kearifan lokal Jambi. & 3 & Baik \\
\hline & & $\begin{array}{l}\text { Materi yang disajikan dapat meningkatkan kemampuan } \\
\text { bahasa siswa kelas II }\end{array}$ & 3 & Baik \\
\hline & \multirow{4}{*}{$\begin{array}{l}\text { Penyajian } \\
\text { Dongeng }\end{array}$} & Kemenarikan tema & 4 & Sangat Baik \\
\hline & & Kesesuaian tema, setting, latar, dan alur cerita. & 4 & Sangat Baik \\
\hline \multirow{2}{*}{4} & & $\begin{array}{l}\text { Makna dongeng dapat membangun karakter positif siswa } \\
\text { kelas II. }\end{array}$ & 3 & Baik \\
\hline & & Kepraktisan bahasa dongeng. & 3 & Baik \\
\hline \multirow{3}{*}{5} & \multirow{3}{*}{ Evaluasi } & Kesesuaian evaluasi dengan tujuan pembelajaran & 3 & Baik \\
\hline & & Kesesuaian evaluasi dengan kemampuan siswa kelas II SD & 3 & Baik \\
\hline & & Kesesuaian evaluasi dengan materi yang disajikan & 3 & Baik \\
\hline \multicolumn{3}{|r|}{ Jumlah } & & 72 \\
\hline \multicolumn{3}{|r|}{ Rata-rata } & & 84 \\
\hline \multicolumn{3}{|r|}{ Persentase Validitas } & \multicolumn{2}{|c|}{86 (Sangat Valid) } \\
\hline
\end{tabular}

\section{Respon Guru}

Setelah melakukan uji coba produk, penulis membagikan angket kepada guru, untuk mengetahui respon terhadap buku dongeng yang dikembangkan, dengan hasil sebagai berikut:

Tabel 4. Angket Respon Guru

\begin{tabular}{|l|l|c|c|}
\hline \multirow{2}{*}{ No } & \multicolumn{1}{|c|}{ Indikator } & \multicolumn{1}{|c|}{ Hasil } \\
\cline { 2 - 3 } & & \multicolumn{1}{|c|}{$\begin{array}{l}\text { Uji Kel. } \\
\text { Kecil }\end{array}$} & $\begin{array}{l}\text { Uji Kel. } \\
\text { Besar }\end{array}$ \\
\hline 1 & Tampilan buku cerita menarik perhatian peserta didik & 4 & 4 \\
\hline 2 & Buku cerita memiliki warna yang menarik & 4 & 4 \\
\hline 3 & $\begin{array}{l}\text { Materi pelajaran pada buku cerita memiliki keterkaitan dengan kehidupan } \\
\text { sehari-hari }\end{array}$ & 3 & 4 \\
\hline 4 & \begin{tabular}{l} 
Buku cerita bergambar sesuai dengan karakteristik peserta didik Sekolah Dasar \\
\hline 5
\end{tabular} & Media praktis saat digunakan oleh peserta didik & 4 \\
\hline 6 & $\begin{array}{l}\text { Buku cerita bergambar membantu guru menyampaikan materi kepada peserta } \\
\text { didik }\end{array}$ & 4 & 4 \\
\hline 7 & Buku cerita bergambar mudah dalam penggunaannya & 4 & 4 \\
\hline 8 & Peserta didik sangat menyukai buku cerita yang memiliki banyak gambar. & 3 & 4 \\
\hline 10 & Ukuran buku sesuai dengan karakteristik peserta didik & 4 & 4 \\
\hline 11 & Bahasa yang digunakan mudah dipahami oleh peserta didik Instrumen & 3 & 4 \\
\hline
\end{tabular}




\begin{tabular}{|c|l|c|c|}
\hline 13 & $\begin{array}{l}\text { Dongeng yang disajikan dapat menambah pengetahuan siswa tentang kearifan } \\
\text { lokal Jambi. }\end{array}$ & 3 & 4 \\
\hline 14 & $\begin{array}{l}\text { Rubrik evaluasi materi dongeng dapat meningkatkan kemampuan bahasa siswa } \\
\text { kelas II. }\end{array}$ & 3 & 4 \\
\hline 15 & Materi yang disajikan sesuai dengan KD dan rumusan indikator. & 3 & 4 \\
\hline 16 & Buku dongeng sangat cocok untuk media pembelajaran guru & 55 & 63 \\
\hline \multicolumn{1}{|c|}{ Jumlah } & 64 & 64 \\
\hline & Rata-rata & $\begin{array}{c}86 \% \\
(\text { Sangat } \\
\text { Baik) }\end{array}$ & $\begin{array}{c}\text { (Sangat } \\
\text { baik) }\end{array}$ \\
\hline
\end{tabular}

\section{Respon siswa terhadap buku dongeng berbasis kearifan lokal Jambi}

Berdasarkan hasil wawancara terstruktuk yang penulis lakukan kepada subyek peneliti setelah melakukan uji coba produk. Pada uji kelompok kecil, peserta didik memberikan respon positif dengan sedikit perbaikan. Pada uji kelompok besar, peserta didik sebagian besar memberikan respon "ya, sangat menarik" terhadap buku dongeng yang dikembangkan. Berdasarkan respon tersebut, maka dapat disimpulkan bahwa buku dongeng berbasis kearifan lokal Jambi sangat praktis dan menarik digunakan sebagai media pembelajaran dongeng kelas II SD/MI.

\section{PEMBAHASAN}

Penelitian ini merupakan mpenelitian Research and Development(R\&D), atau yang dikenal dengan penelitian pengembangan. Penelitian pengembangan ini menghasilkan produk berupa buku dongeng yang valid. Produk yang dikembangkan berdasarkan model 4-D (Define, Design, Develop, and Dessiminate). Validasi dilakukan kepada dua ahli, yakni ahli media dan bahasa. Sugiyono (2016: 45) menjelaskan bahwa "yang dipandang ahli (validator) adalah mereka yang memiliki pengetahuan yang sesuai dengan desain/rancangan yang akan dikaji, serta praktisi adalah orang-orang yang telah biasa menggunakan produk yang sejenis". Pada tahapan pengembangan, penulis telah melakukan validasi dengan sebagaimana mestinya.

Hasil validasi bertujuan untuk mendapatkan produk yang valid, sehingga dapat digunakan untuk mengatasi permasalahan dongeng kelas II MI Al-Munawwaroh Kota Jambi. Berdasarkan paparan hasil validasi di atas. Maka dapat di ulas bahwa penulis mendapatkan angka peningkatan pada proses validasi. Validasi materi dan bahasa memperoleh skor $86 \%$ dengan kriteria Sangat Valid, produk dapat digunakan dengan sedikit revisi. Sedangkan validasi ahli media dan desain penulis lakukan sebanyak tiga kali hingga mendapatkan skor sangat valid. 


\section{KESIMPULAN DAN SARAN}

\section{Kesimpulan}

Berdasarkan proses dan hasil penelitian pengembangan buku dongeng berbasis kearifan lokal Jambi, maka dapat disimpulkan sebagai berikut:

1) Penelitian ini menghasilkan produk berupa buku dongeng berbasis kearifan lokal Jambi yang dikembangkan berdasarkan prosedur 4-D. Proses pengembangan produk model 4-D ada empat tahapan yakni; Define (mendefinisikan). Design(proses desain), produk di desain dengan mengunakan aplikasi Corell Draw, Microsoft publizer dan microsoft word. Develop (mengembangkan), dan Desiminate (menyebarkan).

2) Hasil validasi bahasa memperoleh skor $>85 \%$ (sangat valid), hasil validasi media memperoleh skor $>90 \%$ (sangat valid), respon guru pada uji kelompok kecil dan uji lapangan dengan skor $>85 \%$ dan hanya memerlukan revisi kecil. Revisi tersebut berupa warna backround, ketelitian space dalam penulisan dan petunjuk menggunakan buku guru. Dan kekurangan tersebut telah penulis revisi agar dapat diterapkan lebih baik lagi.

3) Hasil penerapan produk memperoleh skor respon baik dari guru 86 (sangat baik) dan 96\% (sangat baik) pada uji kelompok kecil dan kelompok besar. Berdasarkan hasil wawancara, sebagian besar siswa memberikan respon "sangat menarik" dan siswa dapat menulis dongeng dengan menggunakan buku dongeng yang dikembangkan. Hasil tersebut dapat disimpulkan bahwa buku dongeng berbasis kearifan lokal Jambi menarik dan dapat dijadikan sebagai pelengkap buku tematik tema 7 kurikulum 2013 pada materi dongeng.

\section{Saran}

Saran-saran yang disampaikan berkenaan dengan pengembangan buku dongeng berbasis kearifan lokal Jambi, diantaranya sebagai berikut:

1) Saran Pemanfaatan; Produk pengembangan, dapat digunakan sebagai bahan ajar tambahan atau media untuk menunjang pembelajaran dongeng. Cara meggunakan buku dongeng, dengan mengenalkan dongeng dan cara menulis dongeng kepada siswa, membacakan dongeng kemudian meminta siswa untuk mengerjakan tugas kelompok dan individu. Penelitian ini memiliki beberapa kelemahan diantaranya penelitian ini hanya mengembangkan 3 dongeng Jambi. Penelitian ini hanya diterapkan pada satu kelas saja. Selain itu, penelitian ini memiliki keterbatasan materi dan desain. Untuk itu diharapkan peneliti selanjutnya dapat mengevaluasi dan melakukan penelitian yang lebih baik lagi.

2) Saran Desiminasi; Buku dongeng berbasis kearifan lokal Jambi dapat digunakan dan dimanfaatkan sebagai buku bacaan anak dan suolementari buku kurikulum 2013 tematik tema 7 kelas II SD/MI. Buku ini dapat meningkat keterampilan bahasa dan mendongeng siswa.

3) Saran Pengembangan Produk Lebih Lanjut; Produk pengembangan hanya terfokus kepada kemampuan membaca dan menulis dongeng untuk siswa kelas II saja. Untuk itu, penulis sangat berharap kepada peneliti selanjutnya agar dapat mengembangkan 
bahan ajar dengan menggunakan kurikulum terbaru, menggunakan model pengembangan yang lebih baik lagi.

\section{DAFTAR RUJUKAN}

Amirudin, S. Bakar, H. 2002. Mengenal sastra. Jakarta: CV Indra Jaya.

Asyhar, R. 2010. Kreatif mengembangkan media pembelajaran. Jakarta: Gaung Persada.

Endang. 2011. Evaluasi Proses Suatu Program.Jakarta: Bumi Aksara.

Mulyani, S dan Nana, S. 2006. Perkembangan Peserta Didik. Jakarta: UT. Mulyatiningsih,

Purwaningtyas, Prasetyo. 2017. Statistik Pendidikan. Jakarta Bumi Aksara.

Purnomosidi. 2017. Buku Tematik Kurikulum 2013. Solo: Tiga Serangkai Pustaka Mandiri.

Sanjaya, W. 2008. Perencanaan dan desain sistem pembelajaran. t.t.t: Katalog Dalam Terbitan (KDT).

Sarumpaet, T.K.R. 2009. Pedoman penelitian sastra anak. DKI Jakarta: Anggota IKAPI.

Sujadi. 2003. Metode Penelitian Tindakan. Jakarta: Rineka Cipta.

Wati, R. E. 2016. Ragam media pembelajaran. Bandung: Solusi Distribution.

Sumayana, Y. 2017. "Pembelajaran sastra di sekolah dasar berbasis kearifan lokal (cerita rakyat)". Mimbar Sekolah Dasar. Article Received: 02/02/2017. DOI: 0.23819/mimbarsd.v41.5050. http://ejournal.upi.edu/index.php/mimbar 